\title{
Returning to Frankenstein: the spark of being and the fire of life
}

\author{
Sara Grimes, BA (Hons)
}

Received: 11 August 2019/Revised: 11 August 2019/Accepted: 23 August 2019/Published online: 4 September 2019

(C) Canadian Anesthesiologists' Society 2019

\section{To the Editor,}

As a student of literature, it was very interesting to read "A spark of being": Frankenstein and anesthesiology by Audrey Shafer, ${ }^{1}$ in part, to see how Mary Shelley's revolutionary novel Frankenstein is viewed from a perspective other than the literary. Because of Mary Shelley's expert weaving of the Victor Frankenstein story, it is easy to see how Shafer found a connection between Frankenstein and anesthesiology. While it is true that Frankenstein works exceedingly well as a cautionary tale against the ego of the technologic and medical professions in their seeming ability to play Godwhether it be through the creation of artificial intelligence or bringing someone back from the brink of death-the novel is so much more than that. While Dr. Shafer's reading is valid, some parts fail to take a deeper look into the text itself where the novel sends a strong message about the humane responsibility a medical practitioner has over their patient. Dr. Shafer connects Victor Frankenstein's doom to his rejection of the Creature's hideous appearance. ${ }^{1}$ Nevertheless, it is when Frankenstein is later confronted by the Creature and rejects him again that the fate of Frankenstein's family is sealed as the Creature promises that "I will work at your destruction... so that you curse the hour of your birth". ${ }^{2}$ Victor cannot bear to take responsibility for his Creature and spends the rest of the novel suffering.

This letter is accompanied by a reply. Please see Can J Anesth 2020; 67: this issue.

S. Grimes, BA (Hons) ( $₫)$

Winnipeg, MB, Canada

e-mail: sjmgrimes@gmail.com
Shafer points out in her closing paragraph that monsters, like those in Shelley's novel, are also created when humanity fails to see monsters as anything but monstrous. ${ }^{1}$ While I wholeheartedly agree with that statement, there are deeper lessons to be drawn from Frankenstein. The novel is not just a story about Victor Frankenstein, but also about the Creature itself. Shelley's novel works to remind both Victor and the reader that while the Creature is monstrous in physical appearance, he is still human just like anyone else, and entitled to the same compassion. If anything, what anesthesiologists should take from reading Mary Shelley's Frankenstein is that the significance of what they do while a patient is in their care does not necessarily end once the operation is over and the patient is awake. Mary Shelley's Frankenstein is fraught with anxieties over the creation of life for selfish reasons and it begs everyone to remember not just the spark of life, but also the fire it starts.

Conflicts of interest None declared.

Editorial responsibility This submission was handled by Dr. Hilary P. Grocott, Editor-in-Chief, Canadian Journal of Anesthesia.

\section{References}

1. Shafer A. "A spark of being": Frankenstein and anesthesiology. Can J Anesth 2019. DOI: https://doi.org/10.1007/s12630-01901376-x.

2. Shelley M. Volume II: chapter IX. Frankenstein: or the modern prometheus. In: Macdonald DL, Scherf K (Eds). Frankenstein, $3^{\text {rd }}$ Edition. Peterborough, ON: Broadview Editions; 2012: 156-60.

Publisher's Note Springer Nature remains neutral with regard to jurisdictional claims in published maps and institutional affiliations. 